\title{
KARAKTERISASI SELAI OLES KORO PEDANG (Canavalia ensiformis L.) DENGAN VARIASI PENAMBAHAN SUSU FULL KRIM
}

Characterization of Jack Bean Butter (Canavalia ensiformis L.) with Variation of Full Cream Milk Addition

\author{
Ahmad Nafi' ${ }^{1)} *$, Carolina Hendra Puspita Maqdiz ${ }^{1)}$, Maryanto Maryanto ${ }^{1)}$ \\ ${ }^{1)}$ Jurusan Teknologi Hasil Pertanian, Fakultas Teknologi Pertanian, Universitas Jember \\ Jl. Kalimantan 37, Kampus Tegal Boto Jember 68121 \\ *E-mail: ahmadnafi.ftp@unej.ac.id, carolinahendra@gmail.com
}

\begin{abstract}
Peanut butter is one type of jam that favored by the people. The raw materials of peanut butter such as peanut has a high enough consumption rates but this consumption is not always followed by its productivity. The alternative ingredients in the process of peanut butter production can be substituted by jack bean cause it has lower economic value and good nutrition, but its utilization is still limited. The Utilization of jack bean into a jam requires an additional ingredients to improve its physical, organoleptic and chemical characteristics. Therefore, the additional ingredients that can be used in the production process of jack bean butter is a full cream milk. The purpose of this research is to know the effect of the addition of full cream milk and the amount of its addition to get a good physical, chemical and organoleptic characteristics of jack bean butter.The addition of full cream milk as much as 5\%, 7.5\%, 10\%, 12.5\%, and 15\% of the total water mix and jack bean flour. The results showed that the addition of full cream milk increased the spreadability of jack bean butter, but not affected the lightness. The addition of full cream milk could increase the value of fat, protein and ash content, however this addition reduced water and carbohydrate content. It was improved the acceptance of organoleptic. Addition $12.5 \%$ full cream milk was the best treatment with the lightness 70.72; spreadability $15.90 \mathrm{~cm}$; water content $33.12 \%$; fat content $25.08 \%$; protein content $22.14 \%$; ash content of $0.81 \%$; carbohydrate $18.85 \%$; the preferences of color, flavor, taste, spreadability and overall respectively 4.92; 4.64; 5.08; 5; 5.04 (rather like to likes).
\end{abstract}

Keywords: full cream milk, jack bean, peanut butter

\section{PENDAHULUAN}

Kehidupan modern berpengaruh terhadap pilihan olahan pangan yang dikonsumsi oleh masyarakat. Salah satu olahan pangan yang praktis dan digemari masyarakat adalah selai. Selai merupakan olahan pangan yang berasal dari kacangkacangan atau buah-buahan yang sudah dihancurkan, ditambah gula, dan dimasak sampai mengental (Fachruddin, 2008). Salah satu jenis selai yang cukup digemari oleh konsumen adalah selai kacang. Menurut SNI 01-2979-1992, selai kacang (peanut butter) merupakan salah satu jenis makanan yang berbentuk "pasta" dengan medium minyak, terbuat dari biji kacang tanah sangrai kemudian digiling tanpa atau dengan bahan tambahan.
Potensi penggunaan kacang tanah di Indonesia mengalami peningkatan dari tahun ke tahun. Pada tahun 2011, konsumsi kacang tanah sebesar 748.000 ton meningkat menjadi 785.000 ton ditahun 2013 (Pusat Data dan Sistem Informasi Pertanian, 2013). Namun, peningkatan konsumsi kacang tanah tidak selalu sebanding dengan produksinya. Kementerian Pertanian RI (2017) melaporkan bahwa produktivitas kacang tanah di Jawa Timur mengalami penurunan dari tahun 2016-2017 yaitu $12.80 \mathrm{kw} / \mathrm{ha}$ menjadi $11,89 \mathrm{kw} / \mathrm{ha}$. Menurunnya produksi kacang tanah memerlukan bahan alternatif pengganti dalam pengolahan bahan pangan salah 
satunya dalam pembuatan selai kacangkacangan.

Salah satu bahan alternatif pengganti kacang tanah dalam pembuatan selai kacang-kacangan adalah koro pedang, karena koro pedang memiliki produktivitas yang cukup tinggi dan pemanfaatannya yang belum maksimal. Koro pedang (Canavalia ensiformis L.) termasuk dalam golongan legum atau kacang-kacangan dan merupakan salah satu jenis tanaman lokal yang dapat dengan mudah dijumpai di Indonesia dan memiliki kandungan gizi yang baik. Produktivitas koro pedang mencapai 1-4,5 ton per hektar (Suyanto, 2014). Menurut Sudiyono (2010), kandungan karbohidrat koro pedang mencapai $60,1 \%$, protein $30,36 \%$, dan serat $8,3 \%$. Pemanfaatan koro pedang dapat dijadikan suatu alternatif dalam bahan pangan karena mengandung gizi yang cukup baik. Selain itu, apabila dibandingkan dengan komposisi kimia kacang tanah, koro pedang memiliki komposisi gizi yang tidak kalah baik dengan kacang tanah. Kacang tanah mengandung $20-30 \%$ protein dan $40-50 \%$ lemak.

Salah satu komponen penting dalam pembuatan selai berbasis kacang-kacangan adalah lemak (Mousazadeh et al., 2003). Lemak akan memperkaya rasa, memberi tekstur yang lembut, serta akan meningkatkan mouthfeel, flavor, dan persepsi. Pemanfaatan koro pedang sebagai selai berbasis kacang-kacangan membutuhkan bahan tambahan lain untuk memperbaiki karakteristik fisik dan penerimaan organoleptiknya. Salah satu bahan makanan yang dapat ditambahkan dalam pembuatan selai koro pedang adalah susu full krim. Selain memiliki kandungan lemak yang cukup tinggi, susu full krim juga menandung protein yang dapat berfungsi sebagai emulsifier. Susu full krim dapat memperbaiki aroma dengan memberikan aroma susu. Namun belum diketahui presentase susu full krim dalam pembuatan selai koro pedang untuk menghasilkan selai dengan karakteristik fisik, kimia, dan organoleptik yang baik. Oleh sebab itu perlu dilakukan penelitian pemanfaatan koro pedang menjadi selai dengan penambahan susu full krim yang tepat sehingga didapatkan selai oles dengan karakteristik fisik, kimia dan organoleptik yang baik.

\section{METODE PENELITIAN}

\section{Alat dan Bahan}

Alat-alat yang digunakan dalam penelitian ini adalah baskom plastik (globe), blender (National), loyang staless steel, kompor gas (Rinai), gelas ukur 500 $\mathrm{ml}$ (pyrex), neraca analitik (OHAUS BSA 2245), beaker glass $500 \mathrm{ml}$ (pyrex), Teflon (Maxi), spatula kayu, thermometer air, ayakan tepung. Alat untuk analisis meliputi desikator, cawan porselin, colour reader (CR-300 Konika Minolta), labu kjeldahl, botol timbang, oven listrik (J.P SELECTA 08630 ABRERA ESPANA), perangkat ekstraksi soxhlet.

Bahan dalam pembuatan selai koro pedang antara lain biji koro pedang dari Kabupaten Bondowoso, susu full krim (Indomilk), margarin (Blue Band), garam (Cap Kapal), air, gula kristal putih (Gulaku). Bahan untuk analisis kimiawi antara lain $\mathrm{HCL} 0,1 \mathrm{~N}$, asam borat, selenium, $\mathrm{H}_{2} \mathrm{SO}_{4}$, indikator Methyl Red dan Methyl Blue, heksana, aquades, label, kertas saring.

\section{Tahapan Penelitian}

\section{Pembuatan Tepung Koro Pedang}

Biji koro pedang disortasi untuk memisahkan dengan kotoran atau benda asing. Selanjutnya direndam didalam air dengan perbandingan biji koro dan air 1:3 selama 72 jam. Air rendaman biji koro diganti setiap 6 jam sekali untuk menyediakan air bersih selama proses perendaman. Selanjutnya biji koro pedang dicuci mengguakan air mengalir dan dikupas kulit arinya. Biji koro yang telah dikupas digiling menggunakan blender 
selama 2 menit. Selanjutnya bubur koro pedang dikeringkan menggunakan oven $60^{\circ} \mathrm{C}$ selama \pm 24 jam untuk mengurangi kadar airnya. Selanjutnya, koro pedang yang telah kering digiling menggunaan blender dan diayak dengan ukuran 60 mesh sehingga diperoleh tepung koro pedang.

\section{Pembuatan Selai Koro Pedang}

Pembuatan selai koro pedang diawali dengan penimbangan tepung koro pedang sebesar 50 gram, air $300 \mathrm{ml}$, gula 41,62 gram, garam 2 gram, margarin 45,01 gram dan susu full krim sebanyak 5\%, 7,5\%, $10 \%, 12,5 \%, 15 \%$ (dari total tepung koro pedang + air). Selanjutnya, teung koro pedang, air, gula, garam dan susu full krim bubuk dicampur dan dimasak selama 10 menit dalam suhu $80-90^{\circ} \mathrm{C}$. Setelah 10 menit, ditambahkan margarin dan terus dilakukan pengadukan selama 5 menit hingga diperoleh selai koro pedang.

\section{Rancangan Percobaan}

Penelitian ini menggunakan metode Rancangan Acak Lengkap (RAL) 1 faktor yatu penambahan susu full krim. Susu full krim yang ditambahkan terdiri dari 5 taraf yaitu penambahan susu full krim 5\% (S1), penambahan susu full krim 7,5\% (S2), penambahan susu full krim 10\% (S3), penambahan susu full krim 12,5\% (S4), dan penambahan susu full krim 15\% (S5). Parameter pengamatan dalam penelitian ini yaitu sifat fisik (lightness dan daya oles), sifat organoleptik (kesukaan warna, rasa, daya oles, aroma, keseluruhan), sifat kimia (kadar air, kadar lemak, kadar protein, kadar abu, kadar karbohidrat).

Pengujian sifat fisik dilakukan dengan pengulangan sebanyak 5 kali. Pengujian organoleptik menggunakan panelis semi terlatih sebanyak 25 orang. Tiga sampel perlakuan paling disukai berdasarkan uji organoleptik kesukaan keseluruhan, dilakukan pengujian kimia.

Data pengujian sifat fisik yang telah diperoleh dianalisis menggunakan Analysis of Varian (ANOVA) menggunakan program SPSS, apabila berbeda nyata, maka dilanjutkan menggunakan uji DNMRT (Duncan New Multiple Range Test) pada taraf uji 5\%. Data hasil uji organoleptik, dianalisis secara deskriptif. Tiga sampel terbaik dari uji kesukaan diuji sifat kimianya. Data yang dihasilkan dari uji kimia dianalisis secara deskriptif.

\section{Metode Analisis}

Parameter pengamatan meliputi sifat fisik selai koro pedang antara lain tingkat kecerahan menggunakan colour reader (Subagio, 1997) dan daya oles selai (Yuwono, 1998). Selanjutnya yaitu pengamatan sifat organoleptik menggunakan 25 panelis semi terlatih. Panelis selanjutnya diarahkan untuk melakukan penilaian terhadap kesukaan rasa, warna, aroma, daya oles dan keseluruhan selai dan memberikan skor pada kuisioner yang telah disediakan. Adapun skor nilai kesukaan parameter rasa, warna, aroma, daya oles dan keseluruhan antara lain:

$1=$ Sangat tidak suka

$2=$ Tidak suka

$3=$ Agak tidak suka

$4=$ Agak suka

$5=$ Suka

$6=$ Sangat Suka

7 = Amat Sangat suka

Tiga sampel dengan skor tertinggi berdasarkan kesukaan keseluruhan digunakan sebagai sampel pengamatan sifat kimia yang meliputi kadar air (AOAC, 2005), kadar abu (AOAC, 2005), kadar protein (Sudarmadji et al., 1997), kadar lemak (AOAC, 2005) dan kadar karbohidrat by difference (AOAC, 2005). Untuk menentukan perlakuan terbaik menggunakan uji efektifitas berdasarkan hasil pengujian parameter daya oles, organoleptik (kesukaan warna, daya oles, rasa, aroma dan keseluruhan), kadar protein dan kadar lemak. Uji efektivitas dilakukan dengan pemberian bobot pada 
masing-masing parameter yang digunakan dalam uji efektivitas (De Garmo, 1984).

\section{HASIL DAN PEMBAHASAN}

\section{Karakteristik Fisik Selai Koro Pedang} Lightness (Kecerahan)

Tingkat kecerahan selai koro pedang berkisar antara 70,49 hingga 71,03. Tingkat kecerahan tertinggi terdapat pada perlakuan penambahan susu full krim 5\% sebesar 71,03 dan tingkat kecerahan terendah terdapat pada perlakuan penambahan susu full krim 15\% sebesar 70,49 (Gambar 1). Berdasarkan sidik ragam taraf $(\alpha)$ uji 5\%, menunjukkan penambahan susu full krim dalam setiap perlakuan tidak memberikan pengaruh nyata terhadap tingkat kecerahan selai oles koro pedang yang dihasilkan.

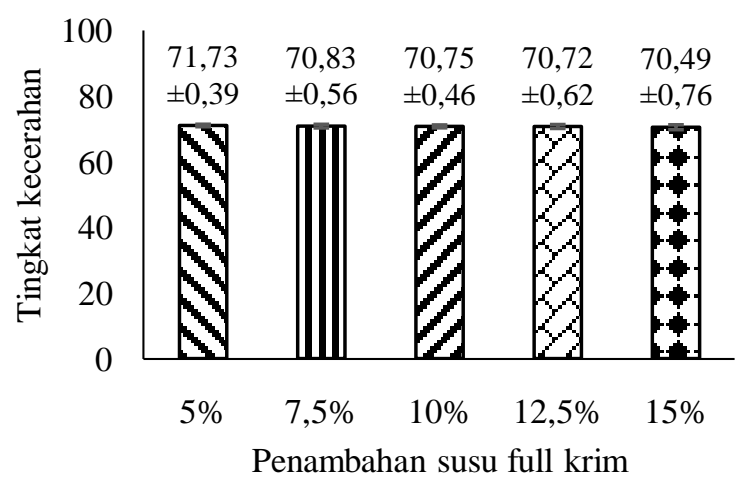

Gambar 1. Nilai tingkat kecerahan selai oles koro pedang

Berdasarkan tingkat kecerahannya, penambahan susu full krim dalam pembuatan selai oles koro pedang menghasilkan warna putih kekuningan. Hal ini disebabkan oleh pigmen warna yang dimiliki susu full krim. Menurut Wangi (2015), penambahan susu full krim dalam suatu produk dapat menghasilkan warna kekuningan yang dibentuk oleh protein (asam amino lisin) dan laktosa dalam susu full krim. Tingkat kecerahan produk merupakan salah satu faktor dalam penerimaan suatu produk oleh konsumen. Nilai L (Lightness) menunjukkan tingkat kecerahan sampel dan berkisar antara 0 sampai dengan 100. Semakin cerah sampel yang diukur maka nilai L mendekati 100, sebaliknya semakin kusam (gelap) maka nilai L mendekati 0 (Gilang et al., 2013).

\section{Daya Oles}

Hasil pengujian daya oles selai koro pedang menunjukkan kisaran nilai antara $11,46 \mathrm{~cm}$ hingga $16,80 \mathrm{~cm}$. Daya oles terendah terdapat pada perlakuan penambahan susu full krim 5\% yaitu sebesar 11,46 $\mathrm{cm}$ dan daya oles tertinggi terdapat pada perlakuan penambahan susu full krim $15 \%$ yaitu sebesar $16,80 \mathrm{~cm}$. Berdasarkan sidik ragam taraf uji $(\alpha) 5 \%$, penambahan susu full krim memberikan pengaruh nyata terhadap daya oles selai koro pedang yang dihasilkan. Nilai daya oles selai koro pedang ditunjukkan pada Gambar 2.

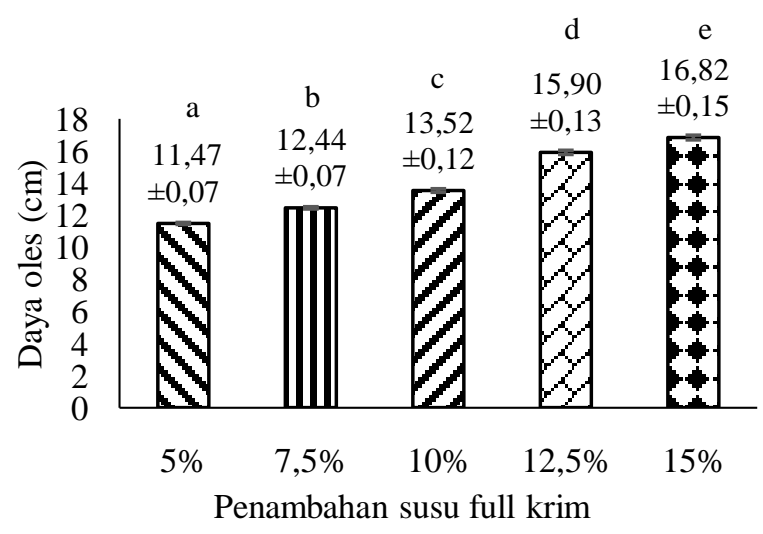

Gambar 2. Nilai daya oles selai oles koro pedang

Penambahan susu full krim mempengaruhi daya oles selai koro pedang yang dihasilkan. Semakin tinggi persentase susu full krim yang ditambahkan, daya oles selai yang dihasilkan juga meningkat. Penambahan susu full krim dengan konsentrasi yang semakin tinggi menyebabkan naiknya kandungan lemak dalam selai. Lemak dalam selai akan bercampur dengan air dan membentuk suatu emulsi. Selain itu, penambahan susu full krim dengan konsentrasi semakin tinggi menyebabkan kandungan protein dalam selai juga meningkat. 
Protein susu dapat berfungsi sebagai emulsifier dalam pengolahan selai koro pedang sehingga dapat menyatukan lemak dan air. Susu full krim mengandung protein sebesar 25\% (Chairunnisa, 2009) yang terdapat kasein didalamnya. Kasein merupakan protein susu yang secara luas banyak digunakan dalam olahan bahan pangan karena memiliki sifat emulsifier yang baik. Menurut Fitria (2010), kasein merupakan protein utama dalam susu yang jumlahnya mencapai kira-kira $80 \%$ dari total protein. Kasein memiliki bagian polar yang berorientasi pada air dan bagian nonpolar yang berorientasi pada minyak.

Peningkatan kandungan protein sebagai emulsifier mampu menstabilkan tegangan permukaan dalam selai sehingga tekstur selai lebih lembut dan merata serta dapat memperbaiki daya oles. Daya oles yang semakin meningkat menggambarkan keadaan selai yang semakin mudah dioleskan, begitu pula sebaliknya daya oles semakin rendah menunjukkan bahwa selai semakin sulit dioles atau kualitasnya buruk (Shakerardekani et al., 2013).

\section{Karakteristik Organoleptik Selai Koro Pedang \\ Kesukaan Warna}

Nilai kesukaan panelis terhadap warna selai koro pedang berkisar antara 4,2 hingga 4,92 yang berarti agak suka hingga suka. Nilai kesukaan warna selai koro pedang tertinggi terdapat pada perlakuan penambahan susu full krim $10 \%$ dan $12,5 \%$ yaitu sebesar 4,92, sedangkan nilai kesukaan warna paling rendah terdapat pada perlakuan penambahan susu full krim 7,5\% sebesar 4,2. Nilai kesukaan warna selai koro pedang ditunjukkan pada Gambar 3.

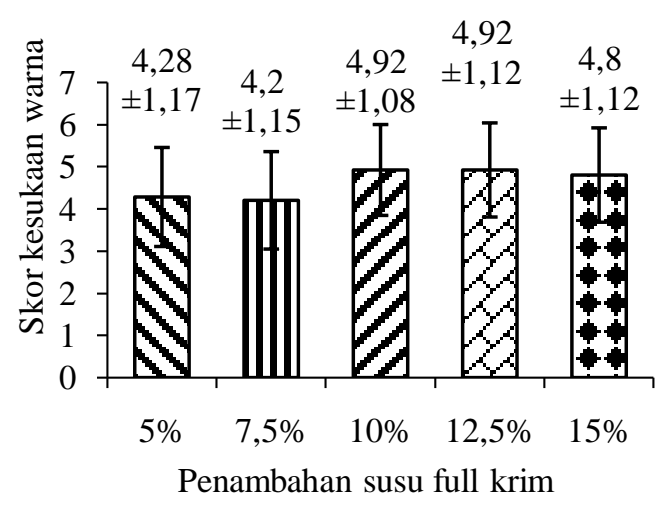

Gambar 3. Nilai kesukaan panelis terhadap warna selai oles koro pedang

Perlakuan penambahan susu full krim $10 \%$ dan $12,5 \%$ mendapatkan nilai tertinggi karena panelis beranggapan bahwa warna selai tersebut memiliki tingkat kecerahan yang lebih dapat diterima dibanding selai dengan perlakuan penambahan susu full krim 5\% dan 7,5\%. Hal ini dapat disebabkan oleh penambahan susu full krim dengan konsentrasi yang semakin kecil menghasilkan pigmen warna yang lebih cerah. Panelis kurang menyukai selai dengan warna yang terlalu pucat, sehingga panelis lebih menyukai selai dengan warna yang lebih gelap. Namun panelis juga tidak terlalu menyukai selai dengan warna terlalu gelap seperti perlakuan penambahan susu full krim $15 \%$ yang memiliki tingkat kecerahan paling rendah dibanding dengan perlakuan lainnya.

\section{Kesukaan Aroma}

Hasil uji organoleptik aroma menunjukkan nilai kesukaan panelis terhadap aroma selai oles koro pedang berkisar antara 3,96 hingga 4,64 (Gambar 4). Nilai tersebut menunjukkan bahwa panelis memberikan penilaian agak suka hingga suka. 


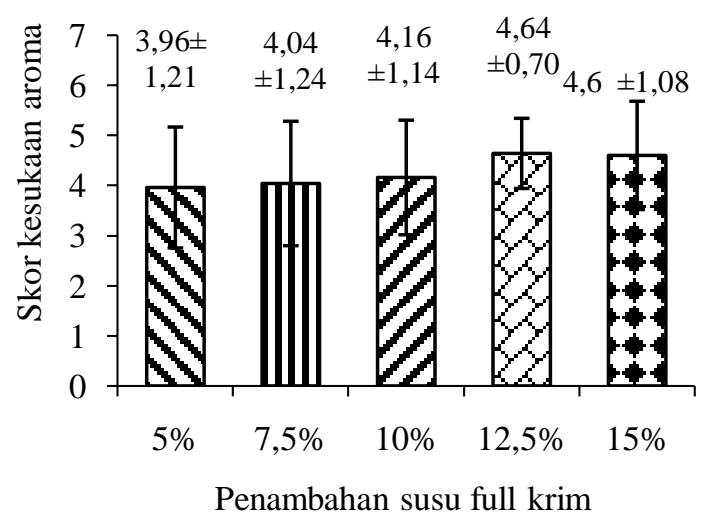

Gambar 4. Nilai kesukaan panelis terhadap aroma selai oles koro pedang

Penambahan susu full krim sebanyak $12,5 \%$ dinilai dapat diterima dan paling disukai oleh panelis (Gambar 4). Hal ini disebabkan penambahan susu full krim sebanyak $12,5 \%$ sudah dapat menutupi bau langu dari koro pedang. Koro pedang memiliki karakteristik bau langu (beany flavor) akibat aktivitas enzim lipoksigenase (Lestari, 2016). Penambahan susu full krim menghasilkan aroma susu pada selai koro pedang. Full krim merupakan jenis susu yang mengandung lemak paling tinggi. Fungsi full krim akan memberikan aroma susu dan mencegah pembentukan kristal yang terlalu besar saat pemasakan. Namun selai koro pedang dengan penambahan susu full krim di atas $12,5 \%$ memiliki nilai kesukaan aroma yang lebih kecil dibanding penambahan 12,5\%. Hal ini dapat disebabkan karena panelis menilai aroma susu yang terlalu kuat memberikan kesan yang kurang disukai.

\section{Kesukaan Rssa}

Nilai kesukaan panelis terhadap rasa selai oles koro pedang berkisar berkisar antara 3,68 hingga 5,12 yang berarti agak suka hingga suka. Gambar 5 menunjukkan bahwa nilai kesukaan rasa tertinggi terdapat pada perlakuan Penambahan susu full krim $15 \%$ dengan nilai 5,12 yang berarti panelis menyukainya. Semakin tinggi konsentrasi susu full krim yang ditambahkan, penilaian panelis terhadap rasa selai oles koro pedang semakin meningkat. Penambahan susu full krim memberikan rasa creamy. Kandungan lemak susu mampu memperbaiki rasa produk yang dihasilkan. Citarasa yang dihasilkan pada lemak susu berasal dari asam lemak (Chairunnisa, 2009).

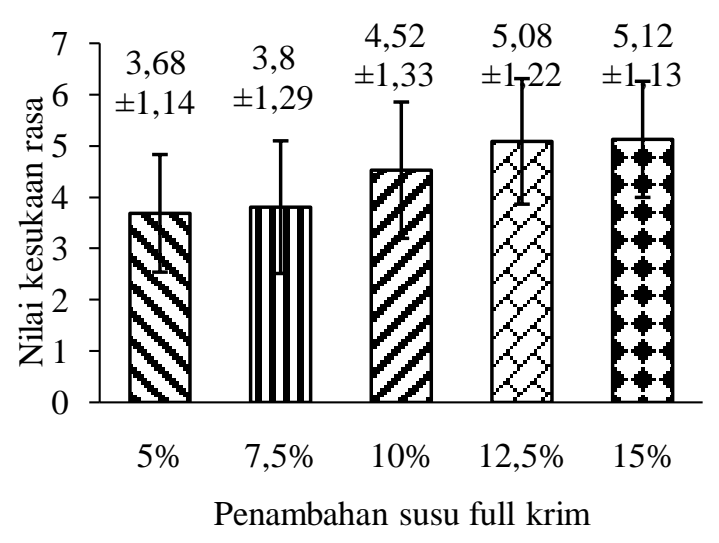

Gambar 5. Nilai kesukaan panelis terhadap rasa selai oles koro pedang

Rasa merupakan karakteristik penting penerimaan selai. Selai berbasis kacang-kacangan dapat diterima oleh konsumen secara luas dengan pertimbangan rasa, selain itu komponen nutrisi juga tidak kalah penting (Shakerardekani et al., 2013).

\section{Kesukaan Daya Oles}

Hasil uji organoleptik daya oles menunjukkan nilai kesukaan daya oles selai koro pedang berkisar antara 4,32 hingga 5, yang berarti panelis memberikan penilaian agak suka hingga suka. Penilaian kesukaan daya oles selai oles koro pedang ditunjukkan pada Gambar 6. 


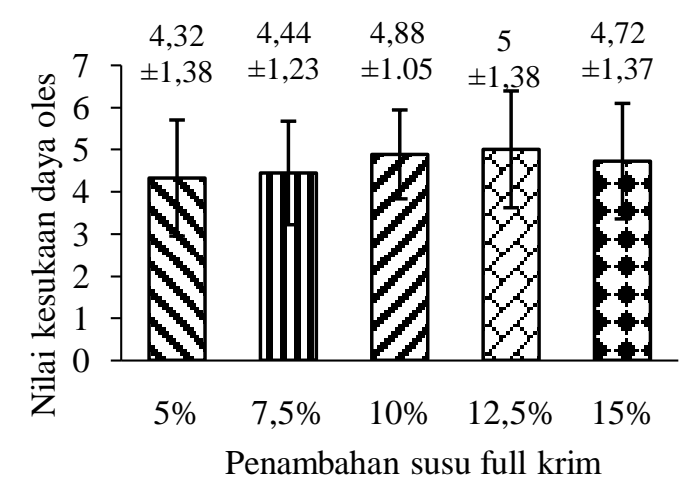

Gambar 6. Nilai kesukaan panelis terhadap daya oles selai oles koro pedang

Perlakuan penambahan susu full krim 12,5\% memiliki nilai kesukaan daya oles tertinggi sebesar 5, yang berarti panelis menyukai daya oles selai. Penambahan susu full krim dengan konsentrasi semakin tinggi memberikan respon panelis yang semakin menyukai daya oles selai, hal tersebut dapat dilihat dari bertambah tingginya rata-rata penilaian. Namun nilai kesukaan panelis menurun pada perlakuan penambahan susu full krim 15\%, hal ini dapat disebabkan panelis lebih tidak menyukai daya oles yang terlalu tinggi. Semakin tinggi konsentrasi susu full krim yang ditambahkan, maka daya oles selai koro pedang semakin tinggi juga dan konsistensinya semakin encer. Tekstur dan daya oles merupakan faktor yang cukup penting pada selai, karena pada umumnya orang mengkonsumsi selai bersamaan dengan roti yang tentunya terjadi proses pengolesan (Putri, 2014).

\section{Kesekuaan Keseluruhan}

Kesukaan keseluruhan merupakan penilaian panelis terhadap atribut secara keseluruhan selai oles koro pedang yang meliputi penampilan secara fisik dan cita rasa yang ditimbulkan. Penilaian kesukaan keseluruhan selai oles koro pedang berkisar antara 4,36 hingga 5,04 yang berarti panelis memberikan penilaian agak suka hingga suka. Perlakuan yang memiliki rata-rata tingkat kesukaan keseluruhan paling tinggi yaitu penambahan susu full krim 12,5\% dengan skor 5,04 yang berarti panelis menyukai selai dengan perlakuan tersebut. Nilai kesukaan yang paling rendah terdapat pada perlakuan penambahan susu full krim 5\% sebesar 4,36 yang berarti agak suka. (Gambar 7).

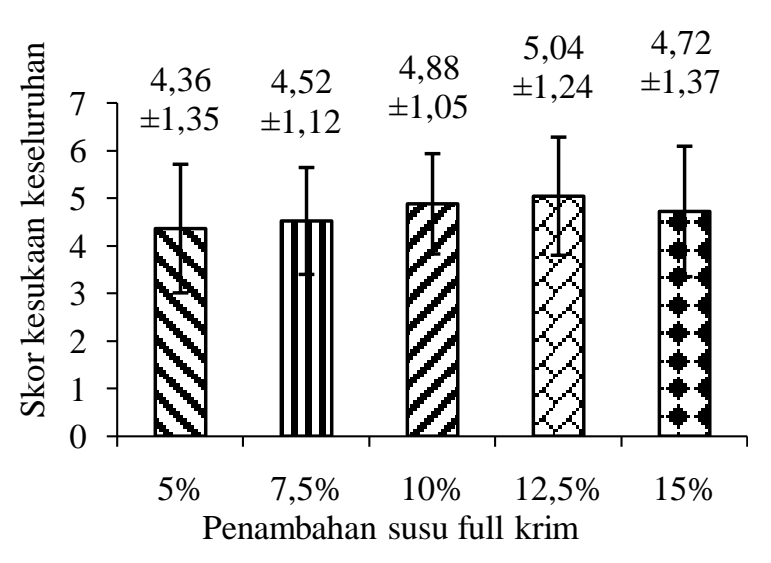

Gambar 7. Nilai kesukaan panelis terhadap keseluruhan selai oles koro pedang

Secara keseluruhan penambahan susu full krim pada selai oles koro pedang memberikan dampak penerimaan yang cukup baik oleh panelis. Tiga sampel terbaik dari uji kesukaan keseluruhan, selanjutnya diidentifikasi kandungan kimianya meliputi kadar air, lemak, protein, dan karbohidrat. Sampel terpilih antara lain S3, S4 dan S5 (penambahan susu full krim 10\%, 12,5\% dan 15\%).

\section{Karakteristik Kimia Selai Koro Pedang Kadar Air}

Kadar air selai koro pedang dengan perlakuan penambahan susu full krim $10 \%, 12,5 \%$ dan $15 \%$ berkisar antara $30,09 \%$ hingga $36,43 \%$ (Gambar 8). Kadar air tertinggi terdapat pada selai koro pedang dengan perlakuan penambahan susu full krim $10 \%$ sebesar 36,43\% dan kadar air terendah terdapat pada perlakuan penambahan susu full krim $15 \%$ sebesar 30,09\%. Penambahan susu full krim dengan konsentrasi yang semakin tinggi 
menyebabkan kadar air selai koro pedang semakin rendah.

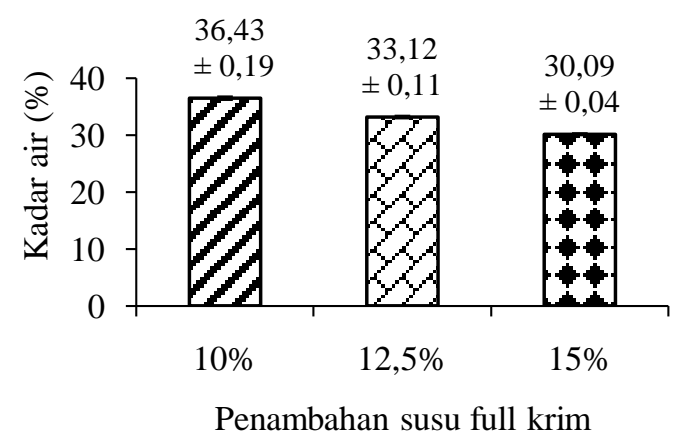

Gambar 8. Kadar air selai oles koro pedang

Kadar air selai koro pedang baik perlakuan penambahan susu full krim $10 \%, 12,5 \%$ dan $15 \%$ belum memenuhi syarat mutu selai kacang-kacangan SNI 01-2979-1992. Berdasarkan SNI 01-29791992, kadar air maksimal dalam selai kacang sebesar 3\%, sedangkan kadar air selai koro pedang berkisar antara 30,09\% hingga $36,43 \%$. Kadar air selai koro pedang yang tinggi dapat disebabkan oleh penambahan air yang cukup tinggi saat proses pembuatan selai sebanyak $300 \mathrm{ml}$. Kadar air selai yang semakin rendah pada penambahan susu full krim yang semakin tinggi, disebabkan oleh bertambahnya jumlah padatan yang terlarut dalam adonan selai. Peningkatan total padatan dalam produk akan menurunkan presentase air yang terkandung dalam produk tersebut, sehingga kadar airnya akan semakin rendah (Fitantri et al., 2014).

\section{Kadar Abu}

Kadar abu selai koro pedang berkisar antara $0,78 \%$ hingga $0,83 \%$. Kadar abu terendah terdapat pada peambahan susu full krim $5 \%$ sebesar $0,78 \%$ dan tertinggi terdapat pada penambahan susu full krim $15 \%$ sebesar 0,83\% (Gambar 9).

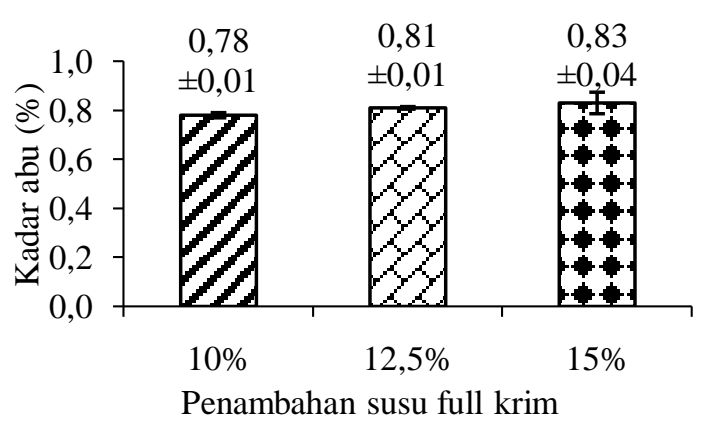

Gambar 9. Kadar abu selai oles koro pedang

Gambar 9 menunjukkan bahwa semakin tinggi jumlah susu full krim yang ditambahkan, maka semakin tinggi pula kandungan kadar abu dalam selai. Kadar abu menunjukkan kandungan mineral yang terdapat pada suatu produk. Selai koro pedang dengan perlakuan penambahan susu full krim 10\%, $12,5 \%$ dan $15 \%$ menghasilkan selai koro pedang yang sudah memenuhi syarat mutu selai kacangkacangan SNI 01-2979-1992 dengan kandungan abu maksimal 2,7\%.

\section{Kadar Protein}

Kadar protein selai koro pedang dengan perlakuan perlakuan penambahan susu full krim 10\%, $12,5 \%$ dan $15 \%$ berkisar antara $21,01 \%$ hingga $24,38 \%$. Kadar protein terendah terdapat pada perlakuan penambahan susu full krim $10 \%$ sebesar $21,01 \%$ dan tertinggi terdapat pada perlakuan penambahan susu full krim $15 \%$ sebesar 24,38\%. Penambahan susu full krim yang semakin tinggi dapat meningkatkan kadar protein selai koro pedang yang dihasilkan.Kandungan protein dalam selai koro pedang tidak seluruhnya berasal dari susu full krim saja, tetapi termasuk dari bahan-bahan lain dalam proses pembuatannya antara lain tepung koro pedang. Kadar protein koro pedang dapat dilihat pada Gambar 10. 


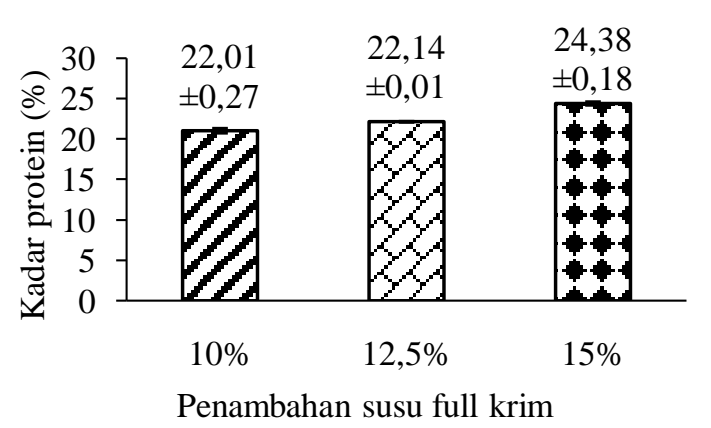

Gambar 10. Kadar protein selai oles koro pedang

Apabila dibandingkan dengan syarat mutu selai kacang SNI 01-2979-1992, selai koro pedang dengan penambahan susu full krim $10 \%, 12,5 \%$ dan $15 \%$ belum memenuhi syarat minimal kandungan protein yaitu minimal $25 \%$. Namun apabila dibandingkan dengan produk selai kacang dipasaran merk "Skippy", selai koro pedang dengan penambahan susu full krim $12,5 \%$ dan $15 \%$ memiliki kadar protein yang lebih tinggi. Kandungan protein pada selai kacang "Skippy" sebesar $21,88 \%$.

\section{Kadar Lemak}

Kadar lemak selai oles koro pedang dengan perlakuan penambahan susu full krim $10 \%, 12,5 \%$ dan $15 \%$ berkisar antara $22,16 \%$ hingga $27,23 \%$ (Gambar 11). Kadar lemak terendah terdapat pada perlakuan penambahan susu full krim $10 \%$ sebesar 22,16\% dan tertinggi terdapat pada perlakuan penambahan susu full krim $15 \%$ sebesar $27,23 \%$.

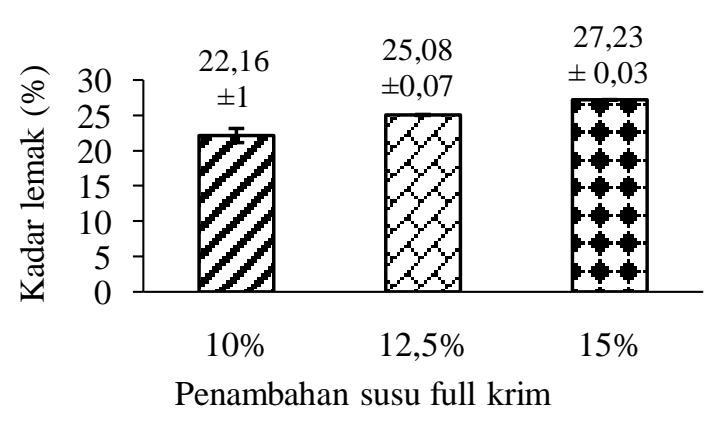

Gambar 11. Kadar lemak selai oles koro pedang
Kadar lemak selai koro pedangsemakin tinggi seiring dengan penambahan susu full krim yang semakin meningkat. Lemak dalam selai koro pedang bersal dari susu full krim, tepung koro pedang maupun margarin. Menurut Buckle et al. (1987) susu full krim mengandung lemak sebesar 26,00\%. Kandungan lemak tersebut yang menyebabkan kadar lemak selai oles koro pedang meningkat.

Menurut SNI 01-2979-1992, syarat mutu kandungan lemak dalam selai kacang berkisar antara $45-55 \%$. Selai koro pedang baik perlakuan S3, S4 dan S5 (Penambahan susu full krim 10\%, 12,5\% dan $15 \%$ ) belum memenuhi syarat mutu SNI selai kacang (SNI 01-2979-1992). Selain itu apabila dibandingkan dengan dengan produk selai kacang dipasaran merk "Skippy", selai koro pedang dengan penambahan susu full krim 10\%, 12,5\% dan $15 \%$ memiliki kadar lemak yang lebih rendah. Kadar lemak selai kacang dipasaran merk "Skippy" mengandung lemak sebesar 53,13\%. Kadar lemak selai koro pedang yang rendah dapat disebabkan karena bahan baku pembuatan selai berupa tepung koro pedang yang memiliki kandungan lemak yang rendah yaitu sekitar 4,46\% apabila dibandingkan dengan selai kacang dengan bahan baku kacang tanah yang memiliki kandungan lemak sekitar $47,7 \%$.

\section{Kadar Karbohidrat}

Kadar karbohidrat selai koro pedang berkisar antara 17,48\% hingga 19,62\%. Kadar karbohidrat selai oles koro pedang terendah terdapat pada perlakuan penambahan susu full krim $15 \%$ sebesar $17,48 \%$ dan tertinggi terdapat pada pelakuan penambahan susu full krim $10 \%$ sebesar 19,62\% (Gambar 10). 


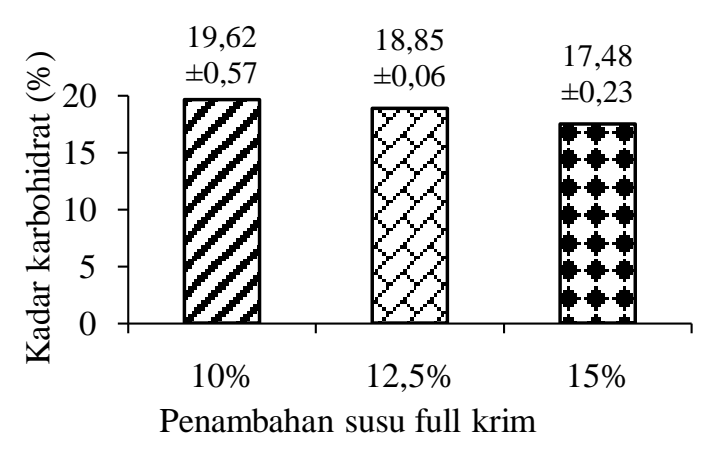

Gambar 12. Kadar karbohidrat selai oles koro pedang

Penambahan susu full krim dengan konsentrasi yang semakin tinggi tinggi, menghasilkan selai dengan kadar karbohidrat yang semakin rendah. Hal ini dapat disebabkan oleh tingginya kandungan lain seperti protein, abu, dan lemak. Apabila dibandingkan dengan produk selai kacang dipasaran merk "Skippy", selai koro pedang dengan penambahan susu full krim 10\%, 12,5\% dan $15 \%$ memiliki kadar karbohidrat yang lebih rendah. Selai kacang merk "Skippy" memiliki kandungan karbohidrat sebesar 21,88\%. Kadar karbohidrat (by different) berdasarkan pengurangan persentase utuh yaitu $100 \%$ dengan kandungan protein, abu, air dan lemak selai. Sehingga dengan penambahan susu full krim yang lebih tinggi menghasilkan rata-rata presentase karbohidrat yang lebih rendah dikarenakan semakin tinggi kandungan lainnya seperti lemak, protein dan abu dalam selai.

\section{Hasil Uji Efektivitas}

Uji efektivitas menghasilkan nilai efektivitas berkisar antara 0,26 hingga 0,50 berdasarkan parameter pengujian fisik berupa daya oles, pengujian organoleptik berupa kesukaan warna, aroma, rasa, daya oles dan keseluruhan dan pengujian kimia berupa kadar lemak dan protein selai oles koro pedang. Nilai uji efektivitas untuk menentukan perlakuan terbaik dalam pembuatan selai oles koro pedang (Tabel 1).
Tabel 1. Hasil uji efektivitas

\begin{tabular}{cl}
\hline Perlakuan & Nilai Efektifitas \\
\hline S3 & 0,26 \\
S4 & 0,50 \\
S5 & 0,23 \\
\hline Keterangan: & S3: selai koro pedang dengan \\
& penambahan susu full krim 10\%, S4: \\
& selai koro pedang dengan \\
penambahan susu full krim 12,5\%, & S5: selai koro pedang dengan \\
penambahan susu full krim 15\%
\end{tabular}

Hasil uji efektivitas menghasilkan sampel selai koro pedang terpilih adalah penambahan susu full krim 12,5\% dengan nilai efektivitas tertinggi yaitu 0,50 . Selai yang dihasilkan memiliki nilai lightness 70,72 ; daya oles $15,90 \mathrm{~cm}$; kadar air $33,12 \%$; kadar lemak 25,08\%; kadar protein $22,14 \%$; kadar abu $0,81 \%$; kadar karbohidrat 18,85\%; kesukaan warna, aroma, rasa, daya oles dan keseluruhan berturut-turut 4,$92 ; 4,64 ; 5,08 ; 5 ; 5,04$ (agak suka hingga suka).

\section{KESIMPULAN}

Penambahan susu full krim berpengaruh terhadap kenaikan daya oles selai koro pedang tetapi tidak berpengaruh terhadap tingkat kecerahan selai. Penambahan susu full krim dengan konsentrasi yang semakin tinggi dapat meningkatkan kadar lemak, protein dan abu, tetapi dapat menurunkan kadar air dan karbohidrat serta dapat memperbaiki penerimaan organoleptik.

Perlakuan penambahan susu full krim $12,5 \%$ merupakan perlakuan terpilih berdasarkan uji efektivitas dengan nilai efektivitas sebesar 0,50. Selai yang dihasilkan memiliki nilai lightness 70,73; daya oles $16,54 \mathrm{~cm}$; kadar air $33,12 \%$; kadar lemak 25,08\%; kadar protein 22,14\%; kadar abu 0,81\%; kadar karbohidrat 18,85\%; kesukaan warna, aroma, rasa, daya oles dan keseluruhan berturut-turut 4,$92 ; 4,64 ; 5,08 ; 5 ; 5,04$ (agak suka hingga suka). 


\section{DAFTAR PUSTAKA}

AOAC. 2005. Official Methods of Analysis. Association of Official Analysis Chemists. AOAC. Inc., Arlington.

Badan Standarisasi Nasional. 1992. Mutu dan Cara Uji Mentega Kacang. SNI 012979-1992. BSN, Jakarta.

Buckle, K.A., R.A Esward, G.H Fleet dan M. Wooton. 1987. Ilmu Pangan. Terjamahan Purnomo dan Adiono. UI Press, Jakarta.

Chairunnisa, H. 2009. Penambahan susu bubuk full cream pada pembuatan minuman fermentasi dari bahan baku ekstrak jagung manis. J. Teknol. dan Industri Pangan, 20 (02): 96-101.

De Garmo, E.P., Sullivan W.G. dan Canada J.R. 1984. Engineering Cecomomy. Seven Edition. Macmillan Publish Company, New York.

Fachruddin. 2008. Membuat Aneka Selai. Kanisius, Yogyakarta.

Fitantri, A.L., N.H.R Parnato., D. Praseptiangga. 2014. Kajian karakteristik sifat fisikokimia dan organoleptiks fruit leather nangka (Artocarpus heterophyllus) dengan penambahan karaginan. Jurnal Teknosains Pangan, 3 (1): 24-26.

Fitria, P. F. 2010. "Fortofokasi pada Produksi Keju Cottage dengan Enzim Papain sebagai Koagulan". Skripsi. Universitas Pendidikan Indonesia, Bandung.

Gilang, R., D. R. Affandi., D. Ishartani. 2013. Karakteristik fisik dan kimia tepung koro pedang (Canavalia ensiformis) dengan variasi perlakuan pendahuluan. Jurnal Teknosains Pangan, 2 (3): 34-42.

Lestari, C.A., T. Widiantara., Hasnelly. 2016. Pengaruh Substitusi tepung koro pedang (Canavalia ensiformis) terhadap karakteristik roti tawar. Jurnal Penelitian Tugas Akhir. Universitas Pasundan, Bandung.
Mousazadeh, M., M. Mousavi., Z. EmamDjomeh., M. Hadinezhad., S.M.T. Gharibzahedi. 2013. Formulation optimation of pistachio oil spreads by characterization of the instrumental textural attributes. International Journal of Food Properties, 12 (6): 1355-1268.

Pusat Data dan Sistem Informasi Pertanian. 2013. Produktivitas Kacang Tanah. (http://pusdatin.setjen.pertanian.go.id/). [Diakses Tanggal 11 April 2017]

Putri, N. K. W. R. 2014. "Pengaruh Fermentasi dan Penambahan Gula dalam Proses Pembuatan Selai Belimbing Wuluh (Averrhoa bilimbi. L.)”. Skripsi. Institut Pertanian Bogor, Bogor.

Shakerardekani, A., R. Karim., H.M. Ghazali., N.L. Chin. 2013. Textural, rheological and sensory properties and oxidative stability of nut spreads - a Review. International Journal of Molecular Sciences, 14 (2): 4223-4241.

Subagio, A. dan N. Morita. 1997. Changes in carotenoids and their fatty acid esters in banana peel during ripening. Food Science Technology, 3 (3): 264-268.

Sudarmadji, S., B. Haryona., dan Suhardi. 1997. Prosedur Analisa untuk Bahan Makanan dan Pertanian. Liberty, Yogyakarta.

Sudiyono. 2010. Penggunaan $\mathrm{Na}_{2} \mathrm{HCO}_{3}$ untuk mengurangi kandungan asam sianida (HCN) koro benguk pada pembuatam koro benguk goreng. Jurnal Agrika, 4 (1): 48-53.

Suyanto, O.C. 2014. "Pengaruh Subtitusi Koro Pedang (Canavalia ensiformis) Terhadap Sifat Fisikokimia dan Organoleptik Selai Kacang”. Tesis. Universitas Katolik Soegijapranata, Semarang.

Wangi, M.P. 2015. "Pemanfaatan Pati Sagu (Metroxylon sagu) dan Koro Pedang (Canavalia ensiformis) dalam Produk Sup Krim Instan". Sripsi. Institut Pertanian Bogor, Bogor. 
Yuwono, S. S., dan Tri, S. 1998. Pengujian Fisik Pangan. Universitas Brawijaya Jurusan Teknologi Hasil Pertanian Fakultas Teknologi Pertanian, Malang 